\title{
Transtorno do déficit de atenção com hiperatividade: causas, sintomas, diagnóstico e tratamento
}

\section{Attention deficit hyperactivity disorder: causes, symptoms, diagnosis and treatment}

\author{
Ana Carolina Parente Viana Rodrigues ${ }^{1}$. Álvaro Jorge Madeiro Leite ${ }^{2}$. \\ 1 Médica Pediatra, Universidade Federal do Ceará (UFC), Fortaleza, Ceará, Brasil. 2 Doutorado em Pediatria pela Universidade \\ Federal de São Paulo (UNIFESP), Professor do Departamento de Saúde Materno Infantil, Universidade Federal do Ceará (UFC), \\ Fortaleza, Ceará, Brasil.
}

\section{RESUMO}

Este trabalho tem como objetivo analisar o Transtorno do Déficit de Atenção com Hiperatividade (TDAH), com base em uma revisão bibliográfica, considerando as contribuições dos autores pesquisados para a conceituação e o entendimento mais aprofundado do distúrbio, oportunizando uma reflexão sobre o TDAH, buscando compreender o transtorno em suas causas, efeitos e formas de tratamento para amenizar seus sintomas. O TDAH vem ocupando lugar de destaque na vida dos pais e também de profissionais de saúde, sendo considerado o principal distúrbio psicológico em crianças. Estudos têm demonstrado que o TDAH aparece com maior frequência na primeira infância, em torno dos 3 anos de idade. O TDAH é um distúrbio neurofisiológico, com sinais de falta de atenção e impulsividade não adequadas ao nível de desenvolvimento, prejudiciais a aprendizagem em crianças, principalmente na idade escolar. Não existe marcador biológico para o TDAH, seu diagnóstico é clínico, baseado em entrevista com o paciente, pais, professores e pessoas que lidam com o portador. Este trabalho foi desenvolvido através de levantamento bibliográfico, obtidos por meio de livros e artigos de revistas científicas especializadas de conteúdo confiável.

Palavras-chave: Transtorno do déficit de atenção com hiperatividade. Criança. Causas. Diagnóstico.

\begin{abstract}
This work aims to analyze the Attention Deficit Hyperactivity Disorder - ADHD, based on a literature review, considering the contributions of the authors searched for the conceptualization and deeper understanding of the disorder, giving the opportunity to reflect on ADHD, trying to understand the disorder in their causes, effects and ways of treatment to alleviate their symptoms. ADHD has occupied a prominent place in the lives of parents and also health professionals and is considered the main psychological disorder in children. Studies have shown that ADHD occurs most often in early childhood, around 3 years of age. ADHD is a neurophysiological disorder with signs of inattention and impulsivity not appropriate to the level of development, detrimental to learning in children, especially at school age. There is no biological marker for ADHD, its diagnosis is clinical, based on interviews with patients, parents, teachers and people who deal with the carrier. This work was developed through literature, obtained through books and articles in technical journals of trusted content.
\end{abstract}

Keywords: Attention deficit disorder with hyperactivity. Child. Causality. Diagnosis.

Autor correspondente: Ana Carolina Parente Viana Rodrigues, Rua Frei Mansueto, 505, apartamento 604, Mucuripe, Fortaleza, Ceará, Brasil. Telefone: +55 85 99188-6631. E-mail: cesar_rodrigues@unilab.edu.br

Conflito de interesses: Não há qualquer conflito de interesses por parte de qualquer um dos autores.

Recebido em: 18 Mai 2016; Revisado em: 07 Jun 2016; Aceito em: 07 Jun 2016.

Como citar:

Rodrigues AC, Leite AJ. Transtorno do déficit de atenção com hiperatividade: causas, sintomas, diagnóstico e tratamento. Rev Med UFC. 2016 jul-dez;56(2):72. 